Comparative Philosophy Volume 11, No. 2 (2020): 90-112

Open Access / ISSN 2151-6014 / www.comparativephilosophy.org

https://doi.org/10.31979/2151-6014(2020).110207

\title{
IZUTSU'S ZEN METAPHYSICS OF I-CONSCIOUSNESS VIS-À-VIS CARTESIAN COGITO
}

\author{
TAKAHARU ODA \& ALESSIO BUCCI
}

\begin{abstract}
Chief amongst the issues Toshihiko Izutsu broached is the philosophisation of Zen Buddhism in his book Toward a Philosophy of Zen Buddhism. This article aims to critically compare Izutsu's reconstruction of Zen metaphysics with another metaphysical tradition rooted in Descartes' cogito ergo sum. Putting Izutsu's terminological choices into the context of Zen Buddhism, we review his argument based on the subject-object distinction and establish a comparison with the Cartesian cogito. A critical analysis is conducted on the functional relationship between subject and object in Izutsu's metaphysics of Zen (meditation). This is examined step by step from the perspective of Descartes' Meditations. On the one hand, we focus on prima facie similarities in meditative and reflective methodologies used by the Zen and Cartesian approaches. On the other, we highlight some unequivocal differences in the metaphysical role of the subject: an indubitable foundation for the epistemological access to objective reality (Descartes), and an introspective apprehension of the egoless void or absolute reality (Zen).
\end{abstract}

Keywords: Cartesian Metaphysics, consciousness, intentionality, meditation, Toshihiko Izutsu, Zen Buddhism

This article critically evaluates Toward a Philosophy of Zen Buddhism (1977), originally written in English, by Japanese philosopher, Toshihiko Izutsu (1914-1993). As a scholar of Eastern religious and philosophical traditions, Izutsu focused particularly on Islam, Daoism, and Buddhism in a distinctive comparative approach. ${ }^{1}$

ODA, TAKAHARU: PhD Candidate in philosophy, Trinity College, Dublin, Ireland. Email: odat@tcd.ie

BUCCI, ALESSIO: PhD Student in philosophy, University of Turin, Italy. Email: alessio.bucci@unito.it

\footnotetext{
${ }^{1}$ However, any general East-West comparison is necessarily historically imprecise. On the scope of Izutsu's comparative works on Eastern thought and mystical philosophy (broadly conceived), including Islamic (e.g. 'irfān, 'knowledge of Allāh'; the Sufi concept of wahdat al-wujūd, 'oneness/unity of being'), Persian, Semitic, ancient Greek philosophies, see Krummel 2019, 558-559; Nakamura 2009, 155; Izutsu
} 
In this spirit, we will present a comparative analysis of Zen Buddhist and Descartes' metaphysics of I-consciousness ${ }^{2}$ and the aboutness (intentionality) of their conscious states to objects. Therein lies an interpretative problem in Izutsu's philosophy that we will discuss.

By the phrase 'philosophy of Zen', Izutsu meant "the philosophical potential hidden in the Zen experience of reality" under the guise of the incompatibility between philosophy and Zen $(1977, x){ }^{3}$ Although any theorizations of Zen may eschew Buddhist 'enlightenment' (in Japanese, kenshō/satori), ${ }^{4}$ we scrutinise Izutsu's metaphysical, non-ontological (i.e. de-ontologized or de-essentialized) attempt constructed on linguistic and epistemic accounts of the Zen self or I-consciousness. We take it that his Zen Buddhist explanation is "metaphysical" insofar as it concerns the "articulation of reality" $(1977, \mathrm{xi})$, in line with traditional and contemporary approaches within the Western philosophical and linguistic framework. Moreover, based on Izutsu's understanding, we reveal how and why Zen I-consciousness can refer to, or relate to, objects (mental representations or ideas), particularly empty ideas like void/nothingness. This is where our critical approach is taken in terms of Izutsu's problematic assumption of "a functional relationship between the subject and the object" in his Zen metaphysics $(1977,8)$. In our final analysis, the intentionality (aboutness or relation) of the Zen subject to their object of thought shall be newly appreciated in a constructive comparison with another type of metaphysical subject, the Cartesian cogito.

In this constructive and deconstructive comparison, we approach Izutsu's Zen metaphysics with Réne Descartes' (1596-1650) metaphysical notion of cogito in the Meditations, or the indubitable thinking self. Thereby one can see why the Cartesian subject and Zen subject take similar steps towards each meditational consequence: egoconstruction (certainty) or ego-deconstruction (nirvāna). The comparison of these philosophical consequences per se might be well known, whereas we show that a careful clarification of the meditator's step by step process to each goal is worth considering. This is because we can understand to what degree similarly and dissimilarly the two different subjects proceed with the respective meditations in

1977, 21, n. 18; 1993, 410-411; Works V, 15-17; X, 634-635. We believe the East-West division is no longer tenable but this remains controversial in the twenty-first century. As to why a cross-cultural, borderless, cosmopolitan philosophy is better promoted, see Garfield 2002, 152-155; Chakrabarti \& Weber 2016, 238: "climb[ing] up to the level playing field of global combative cooperative critical creative philosophy...throw away the ladder of comparison."

${ }^{2}$ We coin the term 'I-consciousness' to disambiguate Izutsu's analysis from debates regarding the self in philosophy of mind and the use of the term 'ego' in psychology (Izutsu 1977, 65-67).

${ }^{3}$ The Japanese zen (in Chinese, chán 禪) is a transliteration of jhān, from the Prākṛt jhāna with the final sound $a$ dropped off (in Samskrtt, dhyāna). It means spiritual 'meditation' or 'contemplation' through physical exercises. See Ui 1935, ii.

${ }^{4}$ There are no equivalent translations between satori/kenshō and 'enlightenment'/'illumination' (both terms are interchangeable in the sense of 'lucid awakening'), but we follow the conventional translations in English given the light metaphor. This is a figurative notion; we adhere to the meaning of a meditative experience of light in (Zen) Buddhism. On the textual sources and practical reports of light, see Lindahl et al. 2014, 6-7. 
relation to their objects of thought (ideas). With reference to historical Zen Buddhism and Cartesianism, ${ }^{5}$ we engage with an in-depth comparison of the two traditions as it concerns the subject-object distinction in the case of meditation. Overall, what we stand to gain from this comparison will be an insight into meditation itself as an approach to philosophical inquiry (in view of the respective logic, language, epistemology, and metaphysics).

To this end, the article is divided into four sections: $\S 1$ delineates Izutsu's philosophization of Zen Buddhism by introducing fundamental Mahāyānist concepts; $\$ 2$ explains early modern French philosopher Descartes' notion of I-consciousness via Izutsu's criticism thereof. By cultivating Descartes' approach to intellectual illumination by analogy with the six-day Creation (Rorty 1986), step by step, $\S 3$ sets out the degree of commonalities between Zen and Cartesian meditations. Finally, $\S 4$ hammers out the contradiction between the two types of meditation, or two types of metaphysical I-consciousness, thereby analyzing the two intentional modes in relation to their objects.

\section{IZUTSU'S PHILOSOPHISATION OF ZEN BUDDHISM}

This first section introduces the basic Zen tenets of Mahāyāna Buddhism, such as "nomind" and "void", in a bid to understand Izutsu's attempt at the philosophization of Zen Buddhism. Izutsu begins his argument stating $(1977,8)$ :

The most fundamental philosophical assertion of Zen at the outset is that there is $a$ functional relationship between the subject and the object, the knower and the known [emphasis added]. Zen begins by recognizing a very close correlation between the state of consciousness of the subject and the state of the objective world which the subject perceives. This correlation between subject and object is of an extremely subtle, delicate, and dynamic nature... between the ego and the world.

The above quote indicates that the objective world that we perceive is structurally determined by the perception of the subject, or our ego-consciousness, which we call 'I-consciousness'. This known world hinges on the way the knower cognises it, for "Zen...always recognizes ...the subject or the ego to be the determining factor" (Izutsu 1977, 8). Thus, Izutsu applies this subject-object epistemic relation to his metaphysical theorization of Zen.

Here, one can first see Izutsu's assimilation of the terms used in so-called Western philosophy, including those of Aristotle, Descartes, Heidegger, and Bertrand Russell $(1977,11)$. Whilst he does not deal with any problem of predicates, Izutsu's philosophical starting point is the distinction between subject and object. However, the terms 'subject' and 'object' themselves are not disputed from any Buddhist perspectives, nor are they noted in the original Samskṛt and Pāli languages of Buddhist

\footnotetext{
5 There has been a historical connection between the Cartesian cogito and Buddhist philosophy in Japan. On the multiple receptions and interpretations of Cartesianism in Japanese intellectual history including Zen Buddhism, see Bonneels \& Derenne 2017.
} 
texts. In fact, the two terms lend themselves to the linguistic framework of Western philosophy in Izutsu's Zen philosophization. To this effect, Izutsu's book (1977) was intended for the comparison with Western philosophy in English, whereas we can see the extent to which his translation and application of Buddhist terms were validly convincing or not. Granted the Western use of philosophical terms and linguistic implication, then, we will overview the Zen Buddhist concepts that he interpreted. The order of our discussion of the following doctrines has neither a degree of importance nor hierarchy, since Buddhist notions are so interlinked and coalesced with one another.

The first is the Zen doctrine of 'no-mind' (Ch. wú-xin; Jp. mushin 無心). This is a metaphysical and psychological state in which the meditator apprehends, or directly experiences, original or absolute reality. According to Izutsu $(1977,15)$ :

The "no-mind" is a psychological state in which the mind finds itself at the highest point of tension, ${ }^{6}$...[a]s an oft-used Zen expression goes: the consciousness illumines itself in the full glare of its own light [emphasis added]. ${ }^{7}$ In this state, the mind knows its object so perfectly that there is no longer any consciousness left of the object; the mind is not even conscious of its knowing the object.

Thus, Izutsu regards the Zen meditator's mind as "supra-consciousness" at the culmination of one's "self-illumination" (1977, 16-17). This is not an unconscious state, but a fully conscious state of one's absolute selfhood as egolessness. ${ }^{8}$ In other words, the supra-consciousness in meditation self-illuminates as internally sinking into "no-mind", to the degree to which one's "self-essence" (Sk. svabhāva; ātman) is deontologized as "lacking self-essence" (nihsvabhāva, "void"). ${ }^{9}$ This no-mind perspective, with no attachment to svabhāva, pertains to the concept of void, discussed below.

The second doctrine concerns the "void" or "emptiness" (Sk. śünyatā; Ch. kōng; Jp. $k \bar{u}$ 空). The Mādhyamika (“adherents of the Middle Way”) like Nāgārjuna,

\footnotetext{
${ }^{6}$ Further interpreting Izutsu's discourse, we take it that this metaphysical-psychological state in Zen meditation refers to nothing ontological in the Cartesian senses of substance and consciousness, reworked from Aristotelian scholasticism (Baker \& Morris 1996, 60-69, 101-112). This Zen state rejects any kind of persistent being in Zen meditation. In other words, 'no-mind' in Zen enlightenment is a deontologized state (neither existence nor non-existence), whereas it can be metaphysically and psychologically interpreted as a lucidly clear state of apprehending absolute reality or egoless void.

${ }^{7}$ One of the critical problems in Izutsu's Zen philosophization is a possible misinterpretation of the light metaphor from ambiguous sources. Notably, in the quoted Zen expression (Izutsu 1977, 15), we could not find from where Izutsu interpreted and defined the illumination of consciousness.

${ }^{8}$ Izutsu (1977, 16, n. 15) thus references the Vajracchedikāprajñāpāramitāsūtra (Diamond Sütra, his translation): "one should never let an abiding mind emerge; a mind thus non-abiding one should let emerge." This explains the 'void' of all things, including one's own ego, to the effect that the assertion of ego is positionless.

${ }^{9}$ As with many Buddhist traditions, Zen meditation attempts to let go of any svabhāva ("self-subsistent and permanently fixed essence") in view of Buddha's teaching in Pạli: sabbe dhammā anattā, i.e. "all things are egoless" (Izutsu 1977, 13; Dhammapāda, verse 279). The Zen doctrine of 'no-mind' is an extension of the early Buddhist doctrine of "no-ego" or "no-self" (Sk. anātman; Jp. muga 無我). See Kasulis 1981, 44.
} 
semantically took a positionless position that language does not correspond to language-independent objects. Thereby they criticiszed the older Abhidharma tradition that ontologised the svabhāva of a 'conditioned object' (samskrta dharma), which was assumed to depend on causes and conditions. Thus, following in the tradition of the Mādhyamika, the Zen concept of kong/kū ('void') is likewise de-ontologized. Overall, even when the void is considered absolute 'nothingness' in the Sino-Japanese context that Izutsu mentions $(1977,27-32$, etc.), we agree with the view that the term śünyatā does not mean the nothing, but "refers neither to existence nor to nonexistence... It is a serious misnomer to identify the ontological position [emphasis added] of Mahāyāna texts as a species of nihilism" (Huntington 1989, 18, n. 5). ${ }^{10}$ Following Nāgārjuna, therefore, Izutsu $(1977,106)$ argues that the term śünyatā refers to "the original metaphysical state of absolute reality where there are no falsely posited, fixed things". As such, it is "not a purely negative ontological state of there being nothing... it is a plenitude of being...as a crystallization of the whole spiritual energy contained therein...the true, absolute ego as Zen Buddhism understands it" (1977, 82). In this sense, the "void" represents the de-ontologized state of no-mind (nihsvabhāva), which relates to "mindfulness" (Sk. smrti; Jp. nen 念) in Zen meditation. In other words, by practicing this meditative mindfulness in daily life, śūnyatā is ultimately realized to be the same as aśünyatā ("non-void') and tathatā ("is-ness" or "suchness"), as typically featured in Mahāyāna Buddhism (Thich 1974, 106-108; Izutsu 1977, 4, 101). Therefore, in this Buddhist egoless supra-consciousness of "no-mind", one may ultimately or truly experience the enlightenment of absolute "void" to which one can relate. This de-ontological doctrine of "void" is supported by the following account of causal relationship.

The third doctrine of (Zen) Buddhism is the notion of "dependent arising" (Sk. pratītyasamutpāda; Ch. yuan-qü; Jp. engi 緣起). Izutsu (1977, 23) clarifies this as a condition where "everything comes into being and exists as what it is by virtue of the infinite number of relations it bears to other things...[as] a system based upon the category of relatio, in contrast to...the Platonic-Aristotelian system which is based on the category of substantia." Historically, refuting the existence of substance-svabhāva, the Mādhyamika embraced the pratītyasamutpāda in support of śūnyatā (Westerhoff 2009, 31, n. 53). Put another way, Buddhist metaphysics of causation ('dependent arising') under "impermanence" (Sk. anity $\bar{a}$, 'phenomenal arising and ceasing') is not rooted in "self-essence" (svabhāva), but in the relation of things, which are in reality 'void'. This indicates that de-ontologising Zen Buddhism is in contradiction with the Aristotelian-scholastic ontology of the substance and nine accidents, from which I-

\footnotetext{
${ }^{10}$ As rightly observed (Izutsu 1977, 59, n. 11), a paradigmatic change occurred when Sengzhao (374414) translated śūnyatā ("void"/“emptiness") in Samskṛt into kong in Chinese, through his Buddhist master Kumārajīva (344-413). The Zen/Chan Buddhist concept of kong ("void" but also "emptiness" or "egolessness") was substantially influenced by Sengzhao's previous education in Laozi's Daoist concept of $w u$ ("nothingness" as the ultimate cause of creation; Jp. $m u$ 無). More historically, the early Indian Mahāyānist concept of śūnyatā denotes nihsvabhāva, the absence of svabhāva ("essence" or "inherent existence"), as espoused by Nāgārjuna (approximately the second century). See also Izutsu 1977, 104 106; Kasulis 1981, 39; Garfield 2002, 66-68; Westerhoff 2009, 19-25, 38, n. 87.
} 
consciousness in Cartesian substance dualism (of the mind and body) emerged (Baker \& Morris 1996, 110, n. 137).

Fourthly, Izutsu construes another Mahāyānist metaphysical doctrine of tathāgatagarbha (Ch. rú-lái-zàng; Jp. nyoraizō 如來藏), which he translates as “the womb of absolute reality", or the matrix permanently actualised through all the phenomenal forms of things (1977, 20-21). By using the linguistic formula "I see this" (subject sees object) as a springboard, Izutsu reconstructs the tathagatagarbha (1977, 20-25). In this absolute metaphysical reality of I-consciousness, Zen experience is never mere theory but immediate reality itself. As Thich Nhat Hanh observes, "Zen is not the study of Zen; Zen is life. Zen is direct contact with reality" (1974, 131). In fact, for his metaphysical-epistemological analysis, Izutsu befittingly interprets Zen literature. Specifically, he deploys the master-disciple anecdotes of $k \bar{o} a n,{ }^{11}$ whereby he unveils a hidden linguistic principle - (I see) in brackets. ${ }^{12}$ By this he means that the Zen 'supra-consciousness' constantly functions through the subject/ego in the objective world (matrix) of tathāgatagarbha. This supra-conscious matrix is formulated according to (1) the subject or ego $S$, and (2) the object $O$, respectively (Izutsu 1977, 21):

(1) $(S \rightarrow) s$

or: (I SEE) myself.

(2) $(S \rightarrow) o$

or: (I SEE) this.

In both linguistic formulas of the verb $S E E$, based on the subject-object semantics and syntax, Izutsu intends to explain the epistemological and metaphysical framework of Zen enlightening experience. When enlightened, the subject-object framework is ultimately reduced to "the pure act of $S E E$ ", to which the term 'no-mind' accurately refers (Izutsu 1977, 22). Here regarding the semantics, the concept of no-mind is comprehensible only if we understand the mind as intrinsically subjective; that is, a mind can be a mind only if there is a subject. Provided that subjectivity is deontologized or de-essentialized in Zen (or Buddhism, more generally), we are

\footnotetext{
${ }^{11}$ On Izutsu's examples of kōan, such as Cypress Tree in the Garden of Zhaozhou (778-897), and the systematization by the Japanese Rinzai Zen Master Hakuin (1685-1768), see Izutsu 1977, 47-55, 117, n. 1 . The kōan is a vast collection of paradoxical sayings, anecdotes, catechism, and mondō ("questions and answers") between the historical monks (generally Chinese) and their disciples. Concerning Japanese Zen meditation, how to use kōan differs between the Sōtō, Rinzai, and Ōbaku Schools. In kōan, there is no logical or semantic connection between a question (e.g. "what is the essence of Zen Buddhism?") and the answer ("the cypress tree in the garden"). There are a variety of non-logical answers by Zen masters to that same question (Nakamura 1985, 110-111).

${ }^{12}$ Izutsu's formulation, albeit original, is emulated from Tsuji Sato's linguistic theory of "I See Myself" in the context of Japanese Zen (Sōtō/Rinzai) schools. What is common between the two scholars is parsing out the underlying structure of reality in experiencing Zen enlightenment (Izutsu 1977, 20, n. 16; Sato 1968, 296-297). On his different formulation of the dynamic structure of Zen 'articulationexperience', see Izutsu 1977, 125-128.
} 
semantically forced to adopt a negative notion. This state of no-mind is represented by the verb $S E E$ without brackets, where "consciousness...is its own self in its pristine purity, a pure Light or sheer Illumination, being illuminated by itself and illuminating itself' (Izutsu 1977, 32). In the full actualization (enlightenment) of reality in tathāgatagarbha, following the first three tenets, the subject can see and become pure void or mind-reality as the whole of I SEE THIS, which is "the eternal now and the ubiquitous here" (1977, 38-40, 54-55). Izutsu here exemplifies the case of Linji (d. 866), who embodied this state of the cosmic ego, grasping the entire universe (or supraconsciousness) within himself, as the "true man without any rank".

Finally, Izutsu (1977, 73-77) explicates a Zen Buddhist mode of being "nonintentional” or “non-thinking” (Ch. fêi-si-liáng; Jp. hishiryō 非思量), by referencing the Chinese Chan/Zen historical masters, Sengcan (Third Patriarch) and Yaoshan Weiyan (d. 834). ${ }^{13}$ Initially, he dovetails the unenlightened Zen dimension of Iconsciousness with manas ("ego-consciousness") 14 of the Yogācāra School (also known as Vijñaptimātratā or "Consciousness-Only" School). Izutsu theorises that in Zen meditation, which developed from this Indian Mahāyānist doctrine, Iconsciousness at the manas level sinks into a "non-intentional" (hishiryō) dimension with no subject-object distinction or 'non-duality' (Sk. advayatā). This is where supraconsciousness self-illuminates without "intending anything, instead of acting as 'subject' as opposed to 'object'" $(1977,77)$. Here, carefully, Izutsu regards hishiryō as a Zen technical term that means the "a-thinking mode of thinking" in "a special dimension of consciousness" "taking place between the 'subject' and the 'object"" (1977, 76-77). ${ }^{15}$ Non-intentional as it may be, we construe there being the Zen subject's aboutness or directedness to the objects of thought. That is, we take it that this

\footnotetext{
${ }^{13}$ Using the example of a renowned mondo (Zen dialogue) between Yaoshan and a visiting monk in the Tang Dynasty, Izutsu (1977, 156-160) extensively explains hishiryō ("thinking-which-is-non-thinking" as "a-thinking thinking" on the basis of fushiryo ("not-to-be-thought-of") or "something which is absolutely unthinkable". This a-thinking form of thinking is regarded as an absolutely "objectless" thinking as actualised "in the void", in which the Zen meditator can just see or be actively aware of their metaphysical state of void (hence also "subjectless"). Izutsu contrasts this Zen mode of thinking with discursive "thinking....in the Cartesian tradition of the West", namely, "conscious manipulation of clear and distinct ideas" $(1977,157)$. On this stark contrast in the two arguments about aboutness, see the fourth section.

${ }^{14}$ In terms of ego-consciousness, Izutsu $(1977,74)$ refers to manovijñanna ("mental consciousness"), which is the sixth consciousness, subsequent to the five sensory consciousnesses. His interpretation is doctrinally misleading as the seventh manas should be identified with ego- or I-consciousness, which is self-obsessed "defiled mind", kliștamanas. This egotistic level is sustained by the eighth and deepest level of ālayavijñāna ("storehouse-consciousness" or "foundation-consciousness") in the Yogācāra eight collections of consciousness. See also Garfield 2002, 138.

${ }^{15}$ Izutsu considers "intentio secunda" (i.e. a concept that is inside the mind, unlike intentio prima that is outside it, or a natural existent) regarding becoming conscious of one's mental state (e.g. in the proposition "I feel happy") $(1977,75-76)$. For the development of primary and secondary intentions in Arabic and medieval logic after (Aristotle and) al-Fārābī (d. 950), in which Iztusu may have been well versed, see Gyekye 1977, 35. Having much to do with the Sautrāntika School in early Buddhism (1977, 75 , n. 6), this "non-intentional" state without intentio secunda is not concerned with the subject-object distinction in Zen. Hence Izutsu does not further explore this mode of intentionality.
} 
Zen mode of inference is captured as a relational theory of intentionality: there is a relation between the subject and the object that is being thought about in a way of nonthinking or just seeing. This is because, in a way similar to prajña ("non-discriminating cognition" or "wisdom") in contrast to a basic inferential activity of the mind, vikalpa ('discriminative cognition'), the Zen subject can freely relate or refer to objects that one apprehends in I-consciousness (Izutsu 1977, 12, 30, 72). ${ }^{16}$ Ultimately, this nonintentional dimension of the meditator is realized "through the yogic, introspective techniques of zazen" $(1977,75)$. That is to be enlightened in the void (śünyatā).

Thus far, if not exhaustively, we summarize that the above interconnected tenets in Mahāyāna Buddhism laid the solid foundation for Izutsu's philosophical analysis of Zen I-consciousness in the state of no-mind. The state is the enlightened supraconsciousness in tathagatagarbha, wherein the subject can relate to or see the object in the non-intentional mode ("a-thinking mode of thinking"). Reconstructing Izutsu's account, Zen meditation represents this metaphysical dynamism and aboutness of nomind, based on his linguistic and epistemic formulation. These Mahāyānist construals are key to understanding what Izutsu intends for a true Zen experience. However, as if unproblematically, these all fit within the Western philosophical and linguistic framework of the subject and object. In other words, in our critical eyes, Izutsu failed to do away with the subject-object distinction in explaining Zen; the distinction was rather a necessary condition for his Zen philosophization. In the next section, we will examine this indispensable way in which he argues against the Cartesian notion of mind within substance dualism, which is to contradict Zen metaphysics that Izutsu philosophizes.

\section{DESCARTES' I-CONSCIOUSNESS VIA IZUTSU'S ZEN PHILOSOPHISATION}

In the first place, Izutsu broaches an argument for Zen supra-consciousness that puts pressure on at least one ontological worldview: Cartesian dualism $(1977,19) \cdot{ }^{17}$ In comparison with that, in this section, we will develop our analysis of Izutsu's Zen metaphysics. Thereby one can more clearly observe Izutsu's understanding of the subject-object distinction, within its contradiction to the Cartesian meditation despite the common effort towards the illumination of the mind.

What is essential to Descartes' dualism is the postulation of two finite "substances"

\footnotetext{
${ }^{16}$ On the Mahāyānist doctrine of 'thoughtlessness' (Jp. munen 無念, "non-conceptual”) stemming from nirvikalpajñāna ("non-discriminative cognition") of the "true nature" (Sk. tathatā; Jp. shinnyo 真如), see the Awakening of Faith in the Mahāyanna (Ch. Da-sheng qi-xin lun 大乘起信論); Thich 1974, 76$77,121-130$. Izutsu metaphysically worked on this sūtra in the form of a posthumous work, which is not yet translated into English (Izutsu 1993).

${ }^{17}$ A critical problem in Izutsu's Zen philosophization is paying no attention to the (transcendental) intersubjectivity in, e.g. Husserlian phenomenological reduction (by phenomenological epochē, the meditating ego is reduced to the meditator's absolute transcendental ego, wherein the objective world is constituted intersubjectively). This indicates important nuances that may fill in the gap between subject and object, as opposed to the Cartesian cogito (Husserl 1960, IV §41; 2001, VI Appendix §§1-2).
} 
irreducible to each other, namely, res cogitans (thinking thing or one's mind) and res extensa (extended objects). ${ }^{18}$ In this Cartesian worldview, according to Izutsu (1977, 19), the independent personal subject or ego is "a detached onlooker confronting a world of external objects". Whilst the Zen meditator has to keep their mind never detached from external objects, the Cartesian onlooker must prove the independent existence of their mind that cannot be doubted. For this purpose, it was vital for Descartes to usher the illumination of the meditator/reader's mind or I-consciousness as detached from corporeal things.

Thus, concerning the root of Descartes' substance dualism, we consider his celebrated proposition: cogito ergo sum ("I think therefore I exist"). ${ }^{19}$ Specifically, in the Meditations on First Philosophy (1641), this cogito proposition is retrospectively examined with "a simple intuition of the mind", but not by syllogistically reasoning the existence from "thought" (cogitatio). ${ }^{20}$ In this cogito argument, however, Descartes' theory of the existence of the mind is indeed arguable. As Alison Simmons points out $(2012,3,16)$, he scantly uses the Latin conscientia or the French conscience and never defines either. ${ }^{21}$ Without a clear distinction between conscious (i.e. self-reflective) and unconscious thoughts, the cogito reasoning (as featured in Meditation II) may not necessarily amount to one's self-knowledge. Moreover, "the very intelligibility of the cogito (which constitutes the ultimate foundation of all knowledge in Descartes' system)" may be questionable (Baker \& Morris 1993, 7, n. 32). This is because the activity of consciousness is not deemed a premise in an argument. ${ }^{22}$ Hence, Descartes'

\footnotetext{
${ }^{18}$ Cartesian mind-body dualism is nowadays contested and contestable. For example, the two concepts can be considered neuroscientifically inseparable, because "the mind exists in and for an integrated organism; our minds would not be the way they are if it were not for the interplay of body and brain during evolution, during individual development, and at the current moment" (Damasio 1994, xvi). On neglected aspects of Descartes' dualism, e.g. theology, empiricism, and a sensitive soul, see Baker \& Morris 1996, 194-198. On a critical review of Cartesian trialism, i.e. mind, body, and the union of them as a third type of substance, see Nolan 2015, 137, nn. 2-3. Our focus is not on justifying dualism, but rather on construing Cartesian meditation thereupon, compared to Zen.

${ }^{19}$ The cogito proposition, with modifications, is registered in Descartes' works and correspondences: "ego cogito, ergo sum" in Principia philosophice I §7 (AT VIIIA 7; CSM I 195); "ego cogito, ergo sum, sive existo" in Meditations (AT VII 140, 205; CSM II 100, 271); "cette vérité: je pense, donc je suis" in Discours de la méthode IV (AT VI 32; CSM I 127); "dubito, ergo sum, vel, quod idem est: cogito, ergo sum" in Recherche de la vérité (unfinished manuscript; AT VII 523; CSM II 417), etc.

${ }^{20}$ AT VII 23-25, 140; CSM II 16-17, 100; Baker \& Morris 1993, 5-6. Descartes argues in Discours IV (AT VI 33; CSM I 127): "this 'I' - that is, the soul by which I am what I am - is entirely distinct from the body... and [the soul] would not fail to be whatever it is, even if the body did not exist." In this cogito argument, what is to be known is the very "I", a narrative subject that is consciousness or res cogitans, whose object is a corporeal thing or res extensa (Kosman 1986, 34-35). One could thereby name the Cartesian I-consciousness, which becomes aware of the self as detached from any objects in this meditational exercise.

${ }^{21}$ On the more detailed account of Cartesian consciousness in view of attentive reflexibility, see Lähteenmäki 2007, 182-185; AT VII 559; CSM II 382. On the historical, Aristotelian-scholastic terms 'conscientia' and 'conscius', which Descartes reworked for his use of self-knowledge or introspection, see Baker \& Morris 1996, 101-118; e.g. AT V 149; CSMK III 335.

${ }^{22}$ On the reading that the dictum sum res cogitans ("I am a thinking thing") is not a definition of one's essence denoted by 'I', see Frankfurt 2008, 166; e.g. AT VII 35; CSM II 24. On the reading that if it
} 
cogito argument may be unsound, even if it is deductively valid in setting up dualist scenarios such as that of the evil demon in the Meditations.

Here the Cartesian cogito, or the mind thinking of one's existence, is clearly undermined from Izutsu's Zen metaphysical perspective that the subject-object distinction is to be defused. This is because the cogito is (Izutsu 1977, 148):

far from being something that leads us directly to the awareness of the reality of human existence; on the contrary, cogito is considered the very source of all delusions about existence; cogito is a distraction that leads us away from an immediate grasp of reality as it really is.

This signifies that the cogito leads strictly and merely to awareness of the existence of a thinking thing, whatever that thing ends up being. Izutsu's suggestion of the cogito as a root of "delusions" about I-consciousness implies the very Buddhist way of defusing the "ignorance" (Sk. avidya $)$ that causes mental "suffering" (duhkha). This fits in the Mahāyānist direction of "non-dual" (advaya) reality, which trenchantly denies the root cause of àtman or svabhāva ("self-essence" or "self-substance") in external objects (Suzuki 1998, 166). Therefore, critically, Izutsu regards the Cartesian conflict between subject and object as "something to be demolished before man begins to see the reality of himself and of so-called external objects" $(1977,20)$. In his refutation of the Cartesian cogito, Izutsu makes use of a Zen expression by Nanquan (749-835): a flower seen in a dream, where "the subject and object, the man and the flower, become fused in an indescribably subtle way into an absolute unity" $(1977,9)$. In this type of Zen experience, awakening after such a dream, the subject stands to realize the tathaggatagarbha matrix uniting themselves and their object in a coherent state of "no-mind" on the supra-conscious level. It can thus be stated that the meditator must practice the egoless no-mind in order to apprehend the tathagatagarbha absolute reality or void.

The above is a brief account of Descartes' dualist approach to the cogito or Iconsciousness in meditation, through the critical lens of Izutsu's Zen philosophization. In the next section, we will examine what the Cartesian and Zen meditators have in common, by expounding upon Descartes' meditational practice.

\section{COMMON FEATURES BETWEEN ZEN AND CARTESIAN MEDITATIONS}

Izutsu's metaphysical philosophization of Zen Buddhism is bound to reject Cartesian dualism. This appears obvious and plain to understand. Nonetheless, the reflection on and realization of the real self from I-consciousness may potentially manifest key common features between Zen and Cartesian meditators. This section sheds light on them comparatively and constructively.

were an argument, the cogito could be an invalid enthymeme lacking a general premise, such as "whatever thinks, exists", see Sarkar 2003, 140-142. We will, in the final section, consider a Cartesian argument about the cogito and its aboutness to objects. 
Whilst withdrawing the mind from bodily senses, Descartes's Meditations also invites the reader to a metaphysical engagement in First Philosophy through meditation. By the first philosophy, Descartes presumably meant to radically reorient the reader's most essential praxis, or spiritual exercise. In fulfilling this meditation, he intended to prove the immortality of the soul (or mind), by clearly and distinctly discerning it, in distinction from every conception of the body (AT VII 12-13, 153154; CSM II 9, 108-109; Baker \& Morris 1993, 26). Descartes believes that we are prone in everyday life to failure to distinguish the self from the body. Hence his meditation is designed to help us observe this clearly. Contrastingly, in Zen Buddhism, as Izutsu claimed, it is presumed that we are prone in everyday life to seeing the self as separate from the other, from the world, from the things we perceive. Hence Zen meditation is meant to help us overcome this illusory separation.

Unlike the Buddhist approach, Descartes infers the cogito for self-verifying, incorrigible, and self-independent existence as a thinking thing. Moreover, due to his Jesuit education, it is highly likely that the Meditations drew on the traditional form of meditation for the illumination (illuminatio) ${ }^{23}$ of cogito, in accordance with Christian literature from St Augustine to St Ignatius of Loyola and Teresa of Ávila. ${ }^{24}$ To this effect, the Meditations was not merely a description of meditation, but designed for the actual practice for one's soul, ${ }^{25}$ as Descartes did "not urge anyone to read this book except those who [were] able and willing to meditate seriously with [him]" (Preface to the Reader; AT VII 9; CSM II 8; Kosman 1986, 41).

Therefore, by transforming the traditional Christian sense of illumination, Descartes presents his version of meditational practice in the Meditations. Here, Amélie Rorty reconstructs "a purely intellectual exercise" of his meditation, by pointing out Descartes" "embarrassing, presumptuous echo of the six days of Creation in the six stages of the Meditations" (Rorty 1986, 8-10, n. 6). The six creational days do not strictly correspond to the six meditations in Descartes' work. ${ }^{26}$ In fact, whilst Stages 4,

\footnotetext{
${ }^{23}$ It should be noted that Descartes does not use this term in Latin, at least not in the Meditations. Nonetheless, we use it as the valid metaphor of I-consciousness that illuminates its object (or perceiving it in the light). See AT VII 59; CSM II 41; Lähteenmäki 2007, 180-181, 199-200.

${ }^{24}$ Rorty 1986, nn. 1-4; Nawar 2016, 25-27; Mercer 2017, 2542; Underkuffler 2019, 5. On typological differences between meditation and contemplation in the history of (Western European) Christian spiritual exercises, see Baier 2019, 85-86. Alternatively, in parallel with the Cartesian cogito meditation, one may consider the Christian mystical tradition of spiritual exercises, such as Pseudo-Dionysius, Meister Eckhart, and St John of the Cross, in comparison with Zen Buddhist void/nothingness, see Williams 2000; Nugent 1996; Ueda 1983.

${ }^{25}$ In a way different to traditional Christian contemplation, Zen Buddhism offers physical practices for meditation, e.g. breathing exercises and zazen ('seated meditation'). Izutsu (1977, 27-28) explicates the Japanese Sōtō Zen Master Dōgen's (1200-1253) teaching of single-mindedly sitting cross-legged in meditation (shikantaza), which induces the experience of an "epistemological-metaphysical state of nothingness" (śünyatā), called "the mind-body dropping off" (shinjindatsuraku). On a more detailed account of Zen practice, see Ueda 1983, 52-58; Ui 1935, viii.

${ }^{26}$ It may well be said that Zen meditation takes countless years for the enlightenment (satori), whereas our analysis does not go into the actual course of time but the figurative six stages or days of Creation. This is purely meant for the comparison between the Cartesian and Zen meditations. On the other hand, never do we ignore stages of "Buddhist meditation" itself in the established, traditional forms, such as
} 
5, and 6 accord roughly with Meditations IV, V, and VI, Rorty (1986, n. 6) allocates Stage 2 to a small part between near the end of Meditation I and a few paragraphs after the beginning of Meditation II (AT IX 17-19 (French); AT VII 22-24 (Latin); CSM II 15-16). This means that much of Meditation II, where Descartes allegedly discovers the indubitable thing or his self-substance whereby laying out his rationalist epistemology, is recounted in Stage 3 of the reflecting part (including Meditation III). However, as is conducive to the comparison with the process of Zen meditation, we will scrutinise the Cartesian cogito meditation towards illumination, using Rorty's reconstruction as follows: ${ }^{27}$

The six days of Creation in Descartes' Meditations

Stage 1: Catharsis, detachment, or analysis: a movement from sensation to imagination and memory, to science and mathematics, to theology.

Stage 2: Skepsis, despair, or nihilism.

Stage 3: Reflection (peripeteia), a reflection that performs a revolutionary change.

Stage 4: Recognition (anagnorisis) of the reflexive, corrective power of the will; the discovery of the law of noncontradiction as a methodological principle validating reductio arguments.

Stage 5: Ascension from the psychological to the ontological order; proofs for the existence of God.

Stage 6: Reconstruction of the world and the self.

The above indicates that Descartes' Meditations establishes the existence of the self in six days, where an adequate pause is given for self-understanding between each meditational day. In other words, Cartesian meditation is reflectively discursive or narrative across time; it should be grasped logically, albeit not through syllogistic reasoning or formal logic. ${ }^{28}$ This aspect may be incompatible with Zen meditation, which does not follow formal logic in the Aristotelian and Cartesian traditions. ${ }^{29}$ In Zen practice, even if logic may be used in the course of experiencing Zen, logic is not a valid procedure for the formation of ultimate knowledge. Therefore, the outcomes of

\footnotetext{
the nine stages of jhāna (progressive cessation) in the Pāli Canon (Ainguttara Nikāya 9.31-36; Bhikkhu Bodhi 2012, 1287-1298).

${ }^{27}$ Otherwise, Mercer $(2017,2549-2553)$ offers another compelling reconstruction based on Teresa of Ávila's Interior Castle (1588), from which Descartes presumably learned how to guide the reader of his Meditations in six steps, when it comes to the deceiver strategy (or demon trope). On a more recent view of St Francis de Sales' influence on Descartes' Meditations, see Underkuffler 2019, 13-15, who is critical about Mercer's reading.

${ }^{28}$ In Rules for the Direction of the Mind (Rule 10; AT X 406; CSM I 36-37), for instance, Descartes rejects syllogism and instead grounds his process of reasoning in intuition, which for him is compatible with mathematical deduction.

${ }^{29}$ In effect, Aristotelian logic, taking a dualistic position (either affirmation of the essence or negation of it) from which Descartes' philosophy critically emerged, contradicts a "logic of not" (Sk. na prthak) as interpreted in the Diamond Sütra (Mahāyāna Buddhist text). This Buddhist logic (i.e. neither affirmation nor negation) is to metaphysically refer or relate to "true void" (Jp. shink $\bar{u}$ 真空), to which Cartesian meditation cannot be truly committed beyond dualism. See Nakamura 1985, 112-113; Nagatomo 2000, 213-215, 222, 238; Izutsu 1977, 12-14, 28-29.
} 
theoretical and practical processes for each illuminated/enlightened self should be divergent. Nevertheless, whilst respecting the analogy with the days of Creation, the Cartesian meditator's illumination of self can to some degree be similar to the Zen practitioner's enlightenment of self, e.g. in doubting one's I-consciousness. The following discusses each stage of Cartesian meditation comparatively.

Stage 1 of catharsis, detachment, or analysis must first discount the argument of theology, to which Zen meditation cannot commit. However, as instructed in the preface to the six parts of the Meditations, the reader or meditational subject is required to proceed with Descartes' clarifying catharsis of the confused ideas of I-consciousness by detaching them from the external world. Descartes states thus: "I will devote myself sincerely and without reservation to the general demolition of my opinions" (Meditation I; AT VII 18; CSM II 12). This leads to an analytic investigation into the mind engaged in meditation, as it "shows the true way by means of which the thing in question was discovered methodically and as it were [epistemically] a priori" (AT VII 155; CSM II 110, clarification added). On the other hand, the Zen meditator takes the direction of enlightenment in realizing themselves to initially be surrounded by objects, or the external world. Thus, on our reading, this starting point of Cartesian catharsis of the subject from what used to be in the world (or object) can be similar to the methodology that Izutsu intended for the Zen meditational subject, who is prima facie dualistically discerned from objects. Indeed, according to Izutsu (1977, 8, quoted above in $\S 1$ ), at first the Zen subject clearly "perceives" external objects or the functional "correlation between subject and object", even if the detachment from the object ends up being mere illusion.

Stage 2 of skepsis, despair, or nihilism expresses a set of existential doubts about I-consciousness (e.g. dreams and the evil demon). Here, Zen "great doubt" (Jp. taiga 大疑; “non-thinking" before "great death" or enlightenment, e.g. in the eighteenthcentury Rinzai Zen Master Hakuin's case; Kasulis 1981, 114-117) seems akin to the ancient Greek skepsis. This is a tranquillising method to overcome skeptical despair (i.e. achieving ataraxia through epochē in Pyrrhonism), which we believe Descartes intended for his own meditation. ${ }^{30}$ In addition to Latin medieval literature, this Greek influence is also closely linked to Cartesian existential angst about any reliable knowledge for oneself (Burnyeat 1982, 34). Therefore, in this stage through each systematic doubt, there may be a similarity between Descartes and Zen regarding nihilism (i.e. uncertainty of the essence of self). In effect, the Cartesian nihilistic despair - "nothing is certain" (Meditation II; AT VII 24; CSM II 16) - of the tortured existence of ego must be considered a rhetorical trope (Rorty 1986, 11-12), whereas Zen meditation should be understood as a stepping stone to the metaphysical-psychological state of 'no-mind' in grappling with despair. However, attempting to deny the essence

\footnotetext{
${ }^{30}$ However, as Burnyeat $(1982,39-40)$ points out, there is an epistemic difference between Descartes and the ancient sceptics, such as Sextus Empiricus. Descartes did not bring skepticism into the practical affairs of life once an indisputable truth of the clear and distinct perception was achieved, whereas the ancients did aim at the life of skepticism by suspending judgement and applying a criterion of truth. See e.g. Meditation III (AT VII 35; CSM II 24); Principia I §3 (AT VIIIA 5; CSM I 193); Letter to Hyperaspistes, August 1641 (AT III 425; CSMK III 191).
} 
of self in Zen meditational "great doubt" may intellectually correspond to Cartesian skepticism about I-consciousness.

Stage 3, reflection (peripeteia), ${ }^{31}$ plays an epistemic or cognitive role in engineering a revolutionary change through skeptical doubts. That is, epistemologically, systematic doubt at some point amounts to something that the meditator knows for certain. In this stage, on our view, one can associate Cartesian reflection with inner, introspective perception (Sk. pratyātmagati) or self-realisation (svasiddhānta) in Zen Buddhism (Lañkāvatārasūtra; Suzuki 1998, 101-105). On the whole, the reflection here indicates the concluding doubt that Descartes proposed, namely, only "my existence" cannot be doubted. As he proceeds with the meditation, "let whoever [i.e. malin génie or evil demon] can do so deceive me, he will never bring it about that I am nothing, so long as I continue to think I am something" (Meditation III; AT VII 36; CSM II 25, clarification added). On this basis of self-reflection, whilst positing "formal reality" in terms of the ontological degrees of ideas, Descartes means "objective reality" about the representational content of ideas to the intellect or mind (AT VII 41-42; CSM II 28-29). Hence, putting aside the respective conclusions of Iconsciousness, Cartesian epistemology (the cogito as a piece of immediate knowledge that only functions in the first-person perspective and the present tense) has a degree of affinity with Zen introspective cognition. For in a way similar to the Cartesian reflection via systematic doubt, the Buddhist meditator has to see inside oneself to such an extent that one may apprehend void.

On the contrary, stage 4, recognition (anagnōrisis) of the reflexive and volitional power that confirms reductio arguments in Descartes, can hardly be compared with Zen meditation. The intellectual illumination of the cogito or "a great light in the intellect was followed by a great inclination in the will" (Meditation IV; AT VII 59; CSM II 41; Hatfield 1986, 52). The force of skeptical doubts is thereby expelled by this volitional power; there is nothing external forcing him to assert that. It is purely the meditator's own will as opposed to the other beliefs that we had been used to since childhood. Then, in a way similar to the will of self-convincing in Cartesian meditation, it may be worth considering the role of volitional force in Zen Buddhism. However, whilst the Cartesian method ultimately returns to recognize a fixed existence of the self, Zen is coherent in cognizing the denial of ego: i.e. no point for recognizing the self-essence (Izutsu 1977, 13). This can be understood through Izutsu's linguistic and epistemic formula (I SEE THIS) in the state of void, wherein the Zen meditator never returns to see a previous meaning of fixed I-consciousness. Here arises a fundamental difference between Cartesian and Zen meditations. Moreover, given that this reductio point about logic concerns more than epistemology and metaphysics, this stage may be highlighted in terms of the dissimilarity between Descartes and Zen. The point is that Zen, e.g. in the use of kōan as one of Zen meditational practices, cannot go about the logical method

\footnotetext{
${ }^{31}$ If we follow Rorty's characterization, peripeteia can be taken as the Aristotelian rhetorical term for the twist-in-the-plot. It is used in Aristotle's Poetics to explain a tragic plot. In this context, it would be a dramatic change in contrast to the previous existential disorientation. This dramatic quality has some aesthetic resemblance to the Buddhist satori ("enlightening awake") in terms of effecting a sudden, lifechanging epistemic moment. See also Husain 2002, 59-60, 96.
} 
of reductio ad absurdum. This is because the Zen master betrays all logical answers of the disciple (i.e. kōan does not proceed through logical argumentation) in order for them to be non-logically enlightened.

As with stage 4 , stage 5 of ascension from the psychological to the ontological order can scarcely be assimilated with Zen meditation. The switch from psychological to ontological analysis appears to be comparable with the stage of metaphysical relation (relatio without substantia) of "dependent arising" (pratītyasamutpāda) in Zen meditation (Izutsu 1977, 23). Nevertheless, one cannot compare Cartesian metaphysical and ontological causation of the psychological self with Zen deontologising causation ("dependent arising") in the state of no-mind, as it is the state of "lacking self-essence" (nihsvabhāva). In fact, phenomenologically, the Cartesian meditator constructs a realist ontology based on "a supremely perfect being", namely, God (Meditation V; AT VII 65; CSM II 45; Rorty 1986, 16). On the other hand, in Zen meditation, the psychological ego (subject) is to be embodied in the state of void, or the metaphysical reality of the tathaggatagarbha matrix (I SEE THIS). For instance, the Japanese Sōtō Zen founder, Dōgen, describes the mental realization of the empirical world, such as a flower realized within the ego (Izutsu 1977, 51). Put another way, there is no divide between subject and object in the enlightened 'supra-consciousness' without substantial essence (svabhāva). Hence, we think that this Zen metaphysicalpsychological realization, as de-ontologized, is not pertinent to the way of ascendance in the Cartesian cogito ontology. This gives rise to further divergent outcomes in the final stage, namely, ego-substance or no-mind.

Stage 6 of reconstruction of the world and the self may be the most controversial aspect for a comparison between the two traditions. Unlike the Cartesian cogito, Zen Iconsciousness is not recomposed as a substance in the meditational process, but rather disassembled or de-ontologized into the absolute no-mind. In this respect, Descartes' constructive reformulation of the corporeal, external world as "objective reality" and the self as "a thinking thing" (Meditation VI; AT VII 78-79; CSM II 54-55) results in an outcome different to the Zen deconstruction of the self. For the Zen subject is to be integrated into the world as absolute void, that is, nirvanna (Izutsu 1977, 60, n. 23). ${ }^{32}$ In the former stages 1 to 3, one may be able to retain the resemblance between Cartesian and Zen meditations. On the other hand, primarily due to stages 4 and 5, it must be clarified that in stage 6 , the consequences between the Cartesian objective world and the Zen absolute no-mind diverge. However, to our mind, whether or not following Descartes, a successful meditator will be able to feel "the relaxation of the senses and the repose of the mind" after the respective exercises (a possible 7th day of

\footnotetext{
${ }^{32}$ See also the "Ten Ox-Herding Pictures" (Jp. jūgyzuzu, 十牛圖, originated in twelfth-century China and well spread in Japan), which schematically portray Zen Buddhist meditation in the ten stages (Ueda 1982, 10-22; 1983, 58-60). In terms of the meditational end of Zen I-consciousness, the tenth or final stage of the Pictures, entitled "Entering the City with Bliss-Bestowing Hands", is telling. In the final picture, when the old herder meets a young human on the road, both reciprocally represent a double self of the herder themselves in virtue of selflessness: I am "I and thou", "I and thou" is I (Ueda 1982, 19-21). This is to return to one's conventional reality but with the ultimate realization of nirvāna.
} 
philosophical sabbath). ${ }^{33}$

Hence, through the six Cartesian stages, one can underscore that at least the first three stages (catharsis, doubt, and reflection) share commonalities regarding metaphysical meditations between Zen and Descartes. However, from stages 4 to 6 (recognition, ascension, and reconstruction), it can be inferred that the consequences differ. The final section will explain why the two meditations end up contradicting each other in their observation and aboutness of I-consciousness.

\section{CONTRADICTORY FEATURES: IZUTSU'S ZEN PHILOSOPHISATION REVISED}

In this final section, we will highlight unequivocal differences in the metaphysical role of I-consciousness: a mental foundation for illumination by one's epistemological access to reality in Descartes, and the inner actualization of one's supra-consciousness, or no-mind, as enlightenment in Zen Buddhism. By clarifying Izutsu's discussion, we will argue that the consequences of the two traditions involve disparate types of metaphysics. On this comparative ground, finally, it shall be understood how and why Izutsu's argument can be undermined in terms of the subject-object "functional relationship" in a relational theory of intentionality that we reformulate.

Cartesian meditation is a guided reading in order for the reader to reveal "a source of impersonal, objective judgments that lies hidden in the intellect" (Hatfield 1986, 69). That is, Descartes' thoughts are listed in a monological fashion, but at the same time the reader is guided to objective reality through different steps of reasoning and intuition. This cognitive exercise can be done only if the reader is logically meditating with their indubitable cogito, i.e. the essence of I-consciousness (AT VII 28; CSM II 19; Baker \& Morris 1996, 13, 167, 205). By contrast, the Zen meditator towards nomind is to betray such an inference as the Cartesian reader (or practitioner) engages in deriving the source of I-consciousness. Hence, despite a certain degree of commonalities between the two traditions, they are meditations of very different types.

Overall, Zen meditation (e.g. by relying on kōan practice between the master and disciple) aims to trigger one's enlightenment through a paradoxical intuition for the ultimate elimination of discursive thinking (Izutsu 1977, 151-155). If this is successful, revising Izutsu's philosophization, the meditator can introspectively attain the absolute state of no-mind, which denies their ontologically persisting "self-essence" (svabhāva). In this context, the Cartesian subject-object dichotomy must be aborted, for Zen reality must represent "non-duality" (advayatā). As Thomas Kasulis $(1981,57,61)$ rightly puts it, "the state of no-mind is supposed to be outside the bifurcation into subject and object...reality is what is now happening - it is not outside our experience. For Zen,

\footnotetext{
${ }^{33}$ On Descartes' own meditational practice for relaxation, see Letter to Princess Elizabeth of Bohemia, 28 June 1643 (AT III 692-693; CSMK III 227): "I can say with truth that the chief rule I have always observed in my studies...has been never to spend more than a few hours a day in the thoughts which occupy the imagination and a few hours a year on those which occupy the intellect alone. I have given all the rest of my time to the relaxation of the senses and the repose of the mind" [emphasis added, au relâche des sens et au repos de l'esprit].
} 
this has the implication that reality is protean, always changing its shape as soon as we come into contact with it and try to pin it down." This type of positionless state that comprises the changing of the entire reality is, to our mind, what Izutsu meant as the metaphysical tathagatagarbha reality. This introspectively defuses the bifurcation of subject and object within the non-intentional (non-thinking) dimension of "supraconsciousness", when and where the meditator is seeing void. Therefore, in this Zen state of being enlightened, the subject-object distinction is something that must be suspended.

However, as understood thus far, the very distinction of "subject" and "object" was presumed to be indispensable for Izutsu's Zen philosophzation. At this juncture, we contend against Izutsu's initial assumption $(1977,8)$ :

The most fundamental philosophical assertion of Zen at the outset is that there is a functional relationship between the subject and the object.

Here we can question: does Zen ("meditation") ever begin with any subject-object functional relationship? Izutsu's mistaken assumption will come to light when we later consider the Zen mode of intentionality in comparison with the Cartesian one. Indeed, in attaining Zen enlightenment, revising Izutsu's linguistic formulas, the verb SEE itself is the de-ontologized "void" without any brackets between the subject and object. Therein, the void is absolute. Solely in the state represented by the verb SEE, the Zen meditator achieves the no-mind or mindfulness in the ordinary but absolute reality of egoless void, which is "the dynamic field in its entirety and wholeness" (Izutsu 1977, 24). In this realization, not only can one let go of the dichotomy between the subject and object, and the mind and body, but also set oneself free from time and space into the eternal now and the ubiquitous here. Therefore, the "I" in Zen enlightenment (satori) is apperceived and apprehended within the metaphysical-psychological state of nomind, or supra-consciousness. Nonetheless, on our reading, this Zen realization does not postulate any necessary object for the meditator from the beginning, for they need not point to any object of thought when meditating. ${ }^{34}$ The void has no indexicality, in other words.

In contrast to Zen, however, the Cartesian meditator retrospectively aims to build analytic reasoning for another metaphysical conclusion (e.g. Discours II; AT VI 1122; CSM I 116-122). That is, when the Cartesian cogito plays at least two roles in the meditation, one of them is to necessarily ground the "certain and unshakable" knowledge of the nature of the mind, as stated in Meditation II (AT VII 24; CSM II 16; Nawar 2016, 26; the other role is to defeat the sceptic). The "I" that thinks now will endure across time, and it is to be ontologically grounded as detached from external things. Descartes (AT VII 25; CSM II 17) therefore "must conclude that this proposition, I am, I exist, is necessarily true whenever it is put forward by me or

${ }^{34}$ Of course, for an instrumental purpose to concentrate on the meditation, Zen beginners do rely on objects, such as numbers to count each breath (Jp. susokukan, 數息觀, “breath-counting”). However, this is preliminary. Zen itself fundamentally does not distinguish any object from the practicing subject. 
conceived in my mind" [emphasis added]. Therein can be posited the indubitable Iconsciousness by means of one's intellectual illumination. ${ }^{35}$

Hence, one can see that the Cartesian methodology, albeit skeptical in nature, epistemically applies systematic doubt in order to find the one thing that is indubitable. In this sense, Descartes carries on the meditation via subtraction, in identifying or illuminating the undeniable I-consciousness. Contrastingly, Zen meditation proceeds by systematically dismantling all the ontological assumptions that guide our reasoning, up to the very extreme of the conflation of object and subject into a non-essential perspective, that is, absolute void. This can be understood as a process of accretion, because a metaphysical category, such as void, is given a whole new epistemic role the role of enlightening the psychological ego with a true understanding of reality in tathägatagarbha.

In the final analysis, in the Cartesian subtractive and Zen accretive approaches to metaphysical I-consciousness, a fundamental difference of their intentionality or aboutness should transpire. Maintaining the original sense of the Latin term intentio in medieval Western philosophy, Izutsu deems the "intentional dimension" of the subject or I-consciousness to be a dualistic "awareness intending something i.e., directed toward something; it is an awareness with an objective reference" (1977, 74-75). This subject-object distinction is the sine qua non of Izutsu's Zen philosophization. However, when it comes to the Zen non-intentional thinking, the postulation of the object as distinguished from the meditator (subject) should be found redundant, pace Izutsu.

To that end, we must constructively compare the intentional modes of Zen and Cartesian I-consciousness in each meditation. This comparison can be reconstructed from the perspective of mental representations that the subject can think (cogitare) about, refer to, or relate to, in particular, an idea of void. ${ }^{36}$ The Cartesian meditator tries but fails to justify a relational theory of intentionality (i.e. there must be a relation between the meditator and the object that is being thought about), whereas the Zen meditator - through Izutsu's philosophizing - justifies it non-intentionally, in the following arguments: ${ }^{37}$

\footnotetext{
${ }^{35}$ The Cartesian meditator thus realizes that "the same 'I' ... has sensory perceptions, or is aware of bodily things as it were through the senses. For example, I am now seeing light" (AT VII 29; CSM II 19; Baker \& Morris 1993, 14).

${ }^{36}$ Within mental representations here we include representations without objects, such as "nothingness" or "void", which one can intend or think about; see e.g. Bolzano's Theory of Science (2014 [1837] I §67). For Bolzano's relational theory of intentionality, entailing the mode of thinking about ideas of nonexistent objects, e.g. "golden mountain", "green virtue", "round square" (Bolzano's examples of logical "ideas in themselves"), see Fréchette 2014, 3-5.

${ }^{37}$ The former Cartesian argument is inspired by Tim Crane's anti-realist noneism, or reductive solution to the problem of non-existence within natural language $(2013,6)$; Crane's treatment is in turn inspired by Husserl's Logical Investigations (2001 [1901], V §11). The latter Zen argument is inspired by Graham Priest's Meinongian solution to the problem of non-existence, based on formal semantics and noneist quantification (i.e. referring to non-existent but possible objects) (2016, 274); see also Meinong's Theory of Objects (1960 [1904], 79).
} 
Cartesian I-consciousness

1. Assume that I think (cogito) about the void. ${ }^{38}$

2. But there is, in reality, no such thing as the void, since nothing comes from nothing. ${ }^{39}$

3. Therefore, a relational theory of intentionality cannot be accepted; my ability to think about a thing does not require that there is, in reality, that thing. (In thinking of the void, I may have an idea of the void, but this does not imply that there is, in reality, the void.)

Izutsu's Zen I-consciousness

1. Assume a relational theory of intentionality (the subject-object "functional relationship"), so my ability to think about a thing requires that there is, in reality, that thing.

2. I can entertain (see) the void in my mind.

3. Therefore, there must be, in reality, such a thing as the void. (This is a metaphysical accretion of the void implying absolute reality.)

We can see that the Cartesian meditator has a reductio argument (jettisoning P1 as there is no relation to the void), whilst the Zen meditator embraces the void. Certainly, premise 1 of the former is rejected in the conclusion. On the other hand, the Cartesian argument's conclusion is denied in premise 1 of our reformulation of Izutsu's argument. However, premise 1 of the latter is ultimately redundant, because the conclusion can follow from premise 2 alone by stressing the relational aspect of the mental representation (as in the formula $S E E$ above mentioned). In fact, the space-time conditions and one's circumstances are all taken away when the subject can realise the empty idea without objectivity. That is, we do not have to presume any "functional relationship between the subject and the object" $(1977,8)$ in Zen meditation when we just see, but cannot point to, the void. Izutsu's argument is, thus, unsound in our reformulation. ${ }^{40}$

The void can be realized in Zen I-consciousness, indeed. This is because the aboutness (directedness) of Zen I-consciousness to the void is metaphysically understood given the non-intentional dimension in no bifurcating or discriminative inference ('a-thinking mode of thinking', hishiryō/prajñā). For Zen I-consciousness, the meditational realization must be non-dual, thereby "non-intentional" (Izutsu 1977, 75):

\footnotetext{
${ }^{38}$ See Meditation III (AT VII 37; CSM II 26): "as far as ideas are concerned, provided they are considered solely in themselves and I do not refer them to anything else, they cannot strictly speaking be false; for whether it is a goat or a chimera that I am imagining, it is just as true that I imagine the former as the latter." Moreover, in terms of pure understanding distinguished from the imagination of false ideas (like chimeras), see Meditation VI (AT VII 72-73; CSM II 50-51): "suppose I am dealing with a pentagon: I can of course understand the figure of a pentagon, just as I can the figure of a chiliagon [a figure consisting of a thousand sides], without the help of the imagination."

${ }^{39}$ Premise 2 can be formulated from the other crucial propositions for Descartes: ex nihilo nihil fit ("nothing comes from nothing") in Meditation III (AT VII 41; IX 33; CSM II 29); AT VII 135; CSM II 97; nihili nulla est proprietas ("nothing has no properties") in AT IIIA 8, 25; CSM I 196, 210, etc. For Descartes' use of the propositions, see Gouhier 1950, 130-131.

${ }^{40}$ In passing, Zen monks and meditators would quash Izutsu's argument that we reformulated in the light of non-logical procedures towards the enlightenment.
} 
The very moment I become aware of myself, my I turns into an objectified I, an "object" among all other "objects". This is the main reason... why it is so difficult to realise the "subject" in its pure subjectivity. One can never hope to actualize the pure ego as long as one remains in the intentional dimension of consciousness.

In this sense, the void itself is de-ontological (without substantial existence): the Zen subject does not posit objective 'self-essence' (svabhāva), nor does they find subjective 'self-essence' in the pratītyasamutpāda causal relation. Thus, Izutsu's Zen understanding of the relational theory of intentionality is, however called nonintentional, considered to be the climax of the subject's metaphysical accretion of absolute void in what he meant by 'supra-consciousness' or 'no-mind'. Nonetheless, it is clear that Izutsu's argument should not be reconstructed by relying on the standard subject-object relationship posited in theories of intentionality.

A full analysis of the Zen conception of "void" (śünyatā) is beyond the scope of this article (but see, e.g. Thich 1974, ch. 5; Nishitani 1982, ch. 4). ${ }^{41}$ That being so, it will now suffice to say that Zen meditation is a robust anti-essentialist stance, in contrast with the Cartesian strategy of overcoming skeptical doubts. More importantly, through this comparative engagement, we are now in the position to see how and why Izutsu's Zen philosophization is criticized: the subject-object relationship is not functional in Zen.

\section{CONCLUSION}

To conclude, we have fleshed out the irreducible distinctions of the ego processes in Zen and Cartesian meditations towards their respective ends. For this purpose, we reviewed Izutsu's Zen philosophization using Mahāyāna Buddhist tenets that converge at the de-ontologized state of no-mind. Criticizing the subject-object distinction that Izutsu presupposed tout court, however, we can now understand that the goals of Iconsciousness in the two traditions are roundly divergent. Revising his Zen metaphysics, thus resoundingly, two types of metaphysical I-consciousness and intentionality of their mental states to objects can be summarized as below:

Cartesian I-consciousness: towards the undoubted existence of oneself in this reality across time through the bifurcating meditation, whence one can refer to objective reality as illuminated by the light of certainty.

Zen I-consciousness: into the no-mind apprehending oneself in this reality now through the meditation without bifurcation or discrimination, whence one can see the void or absolute reality through enlightenment.

\footnotetext{
${ }^{41}$ Nishitani $(1982,164)$ comprehensively yet radically philosophizes the field of śūnyatā as absolute nothingness, or "nothingness-sive-being, being-sive-nothingness", where all beings are "absolutely independent" and "essentially one". This standpoint may be arguable, compared to Izutsu's antiessentialist Zen philosophisation of nothingness or void.
} 


\section{ACKNOWLEDGEMENTS}

We are especially indebted to the comments and suggestions of Anna Ortín, Raquel Bouso, John Krummel, Kenny Pearce, Jim Levine, Graham Priest, Arindam Chakrabarti, Bernard Faure, and the anonymous referees for this journal.

\section{REFERENCES}

Baier, Karl (2019), "Meditation and Contemplation: Two Basic Types of Spiritual Exercises within Western European Christianity", in E.J. Harris \& J. O'Grady (eds.), Meditation in Buddhist-Christian Encounter: A Critical Analysis (Münich: Sankt Ottilien), 59-110.

Baker, G. P., \& Morris, K. J. (1993), “Descartes Unlocked", British Journal for the History of Philosophy 1.1: 5-27. <http://doi.org/10.1080/09608789308570871>

Baker, G. P., \& Morris, K. J. (1996), Descartes' Dualism (London: Routledge).

Bhikkhu Bodhi (trans.) (2012), The Numerical Discourses of the Buddha: A Translation of the Anguttara Nikāya (Boston: Wisdom Publications).

Bolzano, Bernard (2014 [1837]), Theory of Science, 4 vols, trans. P. Rusnock \& R. George (Oxford: Oxford University Press).

Bonneels, Pierre, \& Derenne, Jaime (eds.) (2017), Fortune de la philosophie cartésienne au Japon (Paris: Classiques Garnier).

Burnyeat, Myles F. (1982), "Idealism and Greek Philosophy: What Descartes Saw and Berkeley Missed", The Philosophical Review 91.1: 3-40.

Chakrabarti, Arindam, \& Weber, Ralph (2016), "Afterword/Afterwards", in A. Chakrabarti \& R. Weber (eds.), Comparative Philosophy without Borders (London: Bloomsbury), 227-239.

Crane, Tim (2013), The Objects of Thought (Oxford: Oxford University Press).

Damasio, Antonio (1994), Descartes' Error: Emotion, Reason, and the Human Brain (New York: Avon Books).

Descartes, René (1964-1976), Euvres de Descartes, 12 vols, ed. C. Adam \& P. Tannery, revised edition (Paris: Vrin/CNRS). [Cited as 'AT']

Descartes, René (1984-1991), The Philosophical Writings of Descartes, vols. 1-2, trans. J. Cottingham, R. Stoothoff, \& D. Murdoch; vol. 3, trans. J. Cottingham, R. Stoothoff, D. Murdoch, \& A. Kenny (Cambridge: Cambridge University Press). [Cited as ' $\mathrm{CSM}(\mathrm{K})$ ']

Frankfurt, Harry (2008), Demons, Dreamers, and Madmen: The Defense of Reason in Descartes's Meditations (Princeton: Princeton University Press).

Fréchette, Guillaume (2014), "L'intentionnalité dans la Théorie de la science de Bolzano. Éléments d'une reconstruction", Methodos 14: 1-23. <http://doi.org/ 10.4000/methodos.3826>

Garfield, Jay (2002), Empty Words: Buddhist Philosophy and Cross-Cultural Interpretation (Oxford: Oxford University Press).

Gouhier, Henri (1950), "Les exigences de l'existence dans la métaphysique de 
Descartes", Revue internationale de philosophie 4.12 (1950): 123-152.

Gyekye, Kwame (1971), "'Prima Intentio' and 'Secunda Intentio' in Arabic Logic", Speculum 46.1: 32-38. <https//doi.org/10.2307/2855087>

Hatfield, Gary (1986), "The Senses and the Fleshless Eye: The Meditations as Cognitive Exercises", in A. Rorty (ed.), Essays on Descartes' Meditations (Berkeley: University of California Press), 45-79.

Huntington, Jr., C.W. (1989), with Geshé Namgyal Wangchen, The Emptiness of Emptiness: An Introduction to Early Indian Mādyamika (Honolulu: University of Hawai'i Press).

Husain, Martha (2002), Ontology and the Art of Tragedy: An Approach to Aristotle's Poetics (Albany: State University of New York Press).

Husserl, Edmund (1960 [1931]), Cartesian Meditations: An Introduction to Phenomenology, trans. D. Cairns (Den Haag: Martinus Nijhoff).

Husserl, Edmund (2001 [1901]), Logical Investigations, 2 vols, trans. J. N. Findlay (London: Routledge).

Izutsu, Toshihiko (1977), Toward a Philosophy of Zen Buddhism (Tehran: Imperial Iranian Academy of Science).

Izutsu, Toshihiko (1993), Ishiki no keijijoggaku: Daijōkishinron no tetsugaku [The Metaphysics of Consciousness: The Philosophy of The Awakening of Faith in the Mahāyāna] (Tokyo: Chūōkōronsha).

Izutsu, Toshihiko (2013-2016), Izutsu Toshihiko Zenshū [The Works of Toshihiko Izutsu], 13 vols (Tokyo: Keio University Press).

Kasulis, Thomas (1981), Zen Action / Zen Person (Honolulu: University of Hawai'i Press).

Kosman, Aryeh (1986), "The Naive Narrator: Meditation in Descartes' Meditations", in A. Rorty (ed.), Essays on Descartes' Meditations (Berkeley: University of California Press), 21-43.

Krummel, J.W.M. (2019), "Comparative Philosophy in Japan: Nakamura Hajime and Izutsu Toshihiko", in B. Davis (ed.), The Oxford Handbook of Japanese Philosophy (Oxford: Oxford University Press), 543-561.

Lähteenmäki, Villi (2007), "Orders of Consciousness and Forms of Reflexivity in Descartes", in S. Heinämaa, V. Lähteenmäki, \& P. Remes (eds.), Consciousness: From Perception to Reflection in the History of Philosophy (Dordrecht: Springer), 177-201.

Lindahl, J., Kaplan, C., Winget, E., \& Britton, W. (2014), “A Phenomenology of Meditation-Induced Light Experiences: Traditional Buddhist and Neurobiological Perspectives", Frontiers in Psychology 4.973: 1-16. <https://doi.org/10.3389 /fpsyg.2013.00973>

Meinong, Alexius (1960 [1904]), "The Theory of Objects", trans. I. Levi, D.B. Terrell, \& R. Chisholm, in R. Chisholm (ed.), Realism and the Background to Phenomenology (London: Allen \& Unwin), 76-117.

Mercer, Christia (2017), "Descartes' Debt to Teresa of Ávila, or Why We Should Work on Women in the History of Philosophy", Philosophical Studies 174.10: 25392555. <https://doi.org /10.1007/s11098-016-0737-9> 
Nagatomo, Shigenori (2000), "The Logic of the Diamond Sutra: A is not A, therefore it is A", Asian Philosophy 10.3: 213-244. <https://doi.org/10.1080/095523600200 $11277>$

Nakamura, Hajime (1985), "The Non-Logical Character of Zen", Journal of Chinese Philosophy 12: 105-115. <https://doi.org/10.1111/j.1540-6253.1985.tb00001.x >

Nakamura, Kojiro (2009), "The Significance of Toshihiko Izutsu's Legacy for Comparative Religion", Intellectual Discourse 17.2: 147-158.

Nawar, Tamar (2016), "The Augustinian Cogito and Materialist Theories of Mind", in J. Kaukua \& T. Ekenberg (eds.), Subjectivity and Selfhood in Medieval and Early Modern Philosophy (Dordrecht: Springer), 25-35.

Nishitani, Keiji (1982), Religion and Nothingness, trans. J. van Bragt (Berkeley: University of California Press).

Nolan, Lawrence (2015), "Cartesian Trialism on Trial: The Conceptualist Account of Descartes' Human Being”, in P. Easton \& K. Smith (eds.), The Battle of the Gods and Giants Redux (Leiden: Brill), 137-174.

Nugent, Christopher (1996), "Satori in St. John of the Cross", The Eastern Buddhist 29.1: 52-65.

Priest, Graham (2016), Towards Non-Being: The Logic and Metaphysics of Intentionality (Oxford: Oxford University Press).

Rorty, Amélie (1986), "The Structure of Descartes' Meditations", in A. Rorty (ed.), Essays on Descartes' Meditations (Berkeley: University of California Press), 1-20.

Sarkar, Husain (2003), Descartes's Cogito: Saved from the Great Shipwreck. Cambridge: Cambridge University Press.

Sato, Tsuji (1968), Bukkyō tetsuri [Buddhist Philosophy] (Tokyo: Risōsha).

Simmons, Alison (2012), "Cartesian Consciousness Reconsidered", Philosophers' Imprint 12.2: 1-21.

Suzuki, D.T. (1998), Studies in the Lankavatara Sutra: One of the most important texts of Mahayana Buddhism, in which almost all its principal tenets are presented, including the teaching of Zen (Delhi: Munshiram Manoharlal).

Thich, Nhat Hanh (1974), Zen Keys, trans. A. Low \& J. Low (Garden City: Anchor).

Ueda, Shizuteru (1982), "Emptiness and Fullness: Śn̄nyatā in Mahāyāna Buddhism", trans. J. Heisig \& F. Greiner, The Eastern Buddhist 15.1: 9-37.

Ueda, Shizuteru (1983), “Ascent and Descent: Zen Buddhism in Comparison with Meister Eckhart. Part One”, trans. J. Heisig, The Eastern Buddhist 16.1: 52-73.

Ui, Hakuju (1935), Zenshūshi kenkyū [Studies in the History of Zen School], vol. 1 (Tokyo: Iwanami Shoten).

Underkuffler, Wilson (2019), "Teresa, Descartes, and de Sales: the art of Augustinian meditation", Intellectual History Review 1-24. <https://doi.org/10.1080/174969 77.2019.1648927>

Westerhoff, Jan (2009), Nāgārjuna's Madhyamaka: A Philosophical Introduction (Oxford: Oxford University Press).

Williams, J.P. (2000), Denying Divinity: Apophasis in the Patristic Christian and Soto Zen Buddhist Traditions (Oxford: Oxford University Press). 